Summer 6-1-2004

\title{
Reading as a Criminal in Early Nineteenth-Century Fiction
}

Gary Dyer

Cleveland State University, g.dyer@csuohio.edu

Follow this and additional works at: https://engagedscholarship.csuohio.edu/cleng_facpub

Part of the Literature in English, British Isles Commons

How does access to this work benefit you? Let us know!

Publisher's Statement

Article originally published as Dyer, Gary, "Reading as a Criminal in Early Nineteenth-Century

Fiction," The Wordsworth Circle, Vol. 35, No. 3 (Summer 2004): 141-146.

\section{Recommended Citation}

Dyer, Gary, "Reading as a Criminal in Early Nineteenth-Century Fiction" (2004). English Faculty

Publications. 17.

https://engagedscholarship.csuohio.edu/cleng_facpub/17

This Article is brought to you for free and open access by the English Department at EngagedScholarship@CSU. It has been accepted for inclusion in English Faculty Publications by an authorized administrator of EngagedScholarship@CSU. For more information, please contact library.es@csuohio.edu. 


\section{Reading as a Criminal in Early Nineteenth-Century Fiction}

\section{Gary R. Dyer \\ Cleveland State University}

According to Humphry Potter's A New Dictionary of All the Cant and Flash Languages, first published in 1797, criminals are "better enabled to carry on their Work of Depredation, by using a Language known only to themselves, by speaking and conversing in a barbarous Jargon, unintelligible, and unknown to honest Men." Because criminals possess this jargon, known as "cant" or "flash," "the Shop-keeper and Tradesman find themselves at a Loss, whilst the most daring Offenders openly and before their Faces, converse upon the Practibility of robbing, cheating, or defrauding them" (Potter iii-iv). In A Dictionary of the Slang and Cant Languages (1809), George Andrewes followed Potter in emphasizing that the thieves' jargon was an effective code: "ONE great misfortune to which the Public are liable, is, that Thieves have a Language of their own; by which means they associate together in the streets, without fear of being over-heard or understood." Andrewes aims in his dictionary "to expose the Cant Terms of their Language, in order to the more easy detection of their crimes" (iii).

In Romantic fiction, criminal cant, the dialect of thieves was an encryption, an encoded language that scrambles or conceals its meaning except to the initiates. By adapting or encoding criminal dialect, texts exclude some readers while including others-and leave others stranded between. Since readers can never be certain that the decoding they have performed has uncovered the real meaning, being stranded is the norm.

The "flash," "cant," or "slang" of the criminal classes was fashionable in early nineteenth-century England. Standardized in various editions of Francis Grose's Classical Dictionary of the Vulgar Tongue (first published in 1785), among other lexicons, ${ }^{1}$ it was disseminated through the theater and in novels such as Pierce Egan's popular Life in London (1820-21), illustrated by George Cruikshank, and its theatrical adaptations. Flash dialect appears in poems by Lord Byron and Thomas Moore, and in fiction by Walter Scott, Edward Bulwer, William Harrison Ainsworth, and Charles Dickens. The attention to cant in these literary works is an innovation, insofar as cant was seldom reproduced in earlier English novels depicting criminal society: Henry Fielding uses cant only rarely in Jonathan Wild (1743), and the thieves in William Godwin's Things as They Are (1794) speak the same Godwinian English as the other characters.

In early nineteenth-century England, flash was widely adopted, particularly by those in the boxing subculture. 
When Grose's Classical Dictionary of the Vulgar Tongue was updated as Lexicon Balatronicum in 1811, the reviser noted that Grose had not foreseen back in the 1780s that "young men of fashion would [. . .] be as distinguished for the vulgarity of their jargon as the inhabitants of Newgate" (Lexicon v); "Jon Bee," John Badcock, wrote in his 1823 dictionary of slang that flash, which previously had been limited to "thieves and gamblers," had been adopted by "other kinds of persons" in order to "evince their uppishness in the affairs of life" (Badcock 80). Since underworld language cannot serve a criminal intent unless it remains "unintelligible, and unknown to honest Men," lexicographers like Potter publicized cant in order to subvert it. ${ }^{2}$ Learning flash and using it protects people against criminals who speak it. The cant dictionaries served both purposes, regardless of the authors' real or professed intentions. Moreover, the readers could use flash just like the criminals: the reviser Lexicon Balatronicum (1811) wrote that the dictionary would allow "the whole tribe of second-rate Bang Ups" to "talk bawdy before their papas" (vi), and, thanks to developments in flash language, "improper topics can with our assistance be discussed, even before the ladies, without raising a blush on the cheek of modesty" (vii). Notwithstanding the editor's condescension toward these "second-rate" men, he recognizes the opportunity flash language provided for disguised communication. This slang is useful because it has spread, yet not too far-it had reached young men, but not their fathers or "the ladies."

The fad for slang terms is less significant, however, than the issues raised by their use. In 1823, Badcock defined "flash" as "the language of persons whose transactions demand concealment, yet require that they should mix with those from whom it should be concealed" (79). In other words, the flash of pickpockets and highwaymen was exemplified a wide class of covert communication. Doctors, lawyers, sportsmen, periodical writers, the court, and political radicals, Babcock noted, used analogous forms of slang (158). ${ }^{3}$ One standard meaning of the word "cant" was "A particular form of speaking peculiar to some certain class or body of men," according to Samuel Johnson's Dictionary, and many of these classes were distinct professions (in Johnson's example, Dryden disowned "the proper terms of navigation, land service, or [...] the cant of any profession"). The cant of thieves could serve as a metaphor for the cants used by different professions, such as medicine, law, or literature, to protect their secrets.

In criminal jargon, "flash" meant not only this particular dialect but also the ability to understand the dialect, or to understand an analogous form of encrypted communication. As Badcock observed, "Men who may be unknowing of flash terms or phrases, are said not to be flash, or fla-now corrupted to $f l y$ [. . .]" (79-80). James Hardy Vaux wrote in his 1812 "Vocabulary of the Flash Language" that "to be flash to any matter or meaning, is to understand or comprehend it, and is synonymous with being fly, down, or awake [ . . ]" (2: 174). When Bob Logic in Egan's Life in London is baffled by a term his friends Jerry Hawthorn and Corinthian Tom have chosen as a codeword, he comments, "I am not up to that phrase" (320). " Yet the adjectives "flash," "fly," "up," "down," and "awake" are relative terms. Vaux explained that the phrase "half-flash and half-foolish" meant "a person, who has a smattering of the cant language, and having associated a little with family people, pretends to a knowledge of life which he really does not possess" (2: 179). Tom, the highwayman killed in Canto XI of Byron's Don Juan, who is "full flash" and "so knowing" $(17.7,19.8)$, stands at one end of the spectrum; at the other stands a "flat." Most people, perhaps, stand somewhere between these extremes, a challenging intermediate state in which one is uncertain how fully flash he is. When flash terms became more commonplace in the Romantic era, so, too, did the taxonomy of knowingness. In Life in London, Jerry Hawthorn explores the capital city with the guidance of his cousin Tom and their friend Bob Logic, in which Jerry's education in London "life" involves not only touring Carlton Palace and going to the theatre but serving a novitiate in knowingness. Tom warns Jerry that a man-abouttown must be humble: "do not let it be said of you, sneeringly, that you are quarter FLASH, and three parts FOOLISH!!!" He advises his cousin, "whisper into your own ear, and make an allowance that there are to be found in company persons as knowing as yourself, if not more knowing!" (143-44).

Writers take various approaches to flash. Some novelists and poets who record flash verbatim help their readers to understand it, but others leave them confused. Pierce Egan, who explains slang in footnotes throughout Life in London, observes that "some of my readers of a higher class of society, may feel [. . . ] that I have introduced a little too much of the slang, but I am anxious to render myself perfectly intelligible to all parties." He implies that readers will object to the opacity of slang. He goes on to say, "A kind of cant phraseology is current from one end of the Metropolis to the other," and since "Half of the world are up to it," he will "make the other half down to it" (84 n2). Once the readers are "down," they will understand not only Egan's book but also conversations throughout London. Deciphering itself, Life in London prepares the reader to decipher London life.

Edward Bulwer takes a different approach in Pelham (1828). The aristocratic protagonist Henry Pelham must infiltrate a band of criminals, and the guide who will accompany him, Job Jonson, prepares him with lessons in "St. Giles's Greek" (404). Bulwer's reader never gets a chance to evaluate Jonson's tutelage, since, as things turn out, Pelham never has to utter any flash, but the reader does encounter flash conversations-Pelham's visit to the thieves' house (414-17) provides the densest flash speech in early nineteenth-century literature. Yet Bulwer, at least in the early editions of Pelham, provides almost no help for the reader who wishes to follow the dialogue. In this respect, Bulwer imitates his idol Byron, whose note on the flash in Don Juan Canto XI is more teasing than helpful (Dyer 564). 
Three examples from early nineteenth-century fiction of what might be termed the half-flash scene: in Scott's Guy Mannering (1815), in “The Surgeon's Daughter” (published in Chronicles of the Canongate in 1827), and in Bulwer's Paul Clifford (1830), in which a man finds himself amid criminal flash society, and is confused by what he hears, although his inferences are correct. The intriguing aspect of these scenes in Guy Mannering, "The Surgeon's Daughter," and Paul Clifford is the way they draw boundaries among four figures or groups: first, the characters who speak flash; second, the narrator; third, the character who is perplexed by the flash speech; and, fourth, the reader. The texts assign different levels of awareness to each of these four groups: one seems more flash to what is said than another, yet it is not clear who, if anyone, is full flash.

In Guy Mannering, Vanbeest Brown (really Harry Bertram) eavesdrops on a cant conversation after he accidentally wanders into a hideout for thieves. Meg Merrilies, wishing to protect the man she recognizes as the heir to the Ellangowan estate, escorts "Brown" to a hiding-place moments before five men enter, three of them apparently gypsies like Meg. For a while, Scott transcribes Meg's and the men's conversation, including its numerous cant terms- "kinchin-mort" for girl, "darkmans" for night, "flats" (148-49)—without indicating whether Bertram understands what he hears. ${ }^{5}$ When Meg withdraws to sleep, however, Scott reveals Bertram's response: "the low tone in which they spoke, and the canting language which they used, prevented Bertram understanding much of their conversation," (149) but he "gathered in general, that they expressed great indignation against some individual." The exchanges Scott transcribes make Bertram's inferences correct:

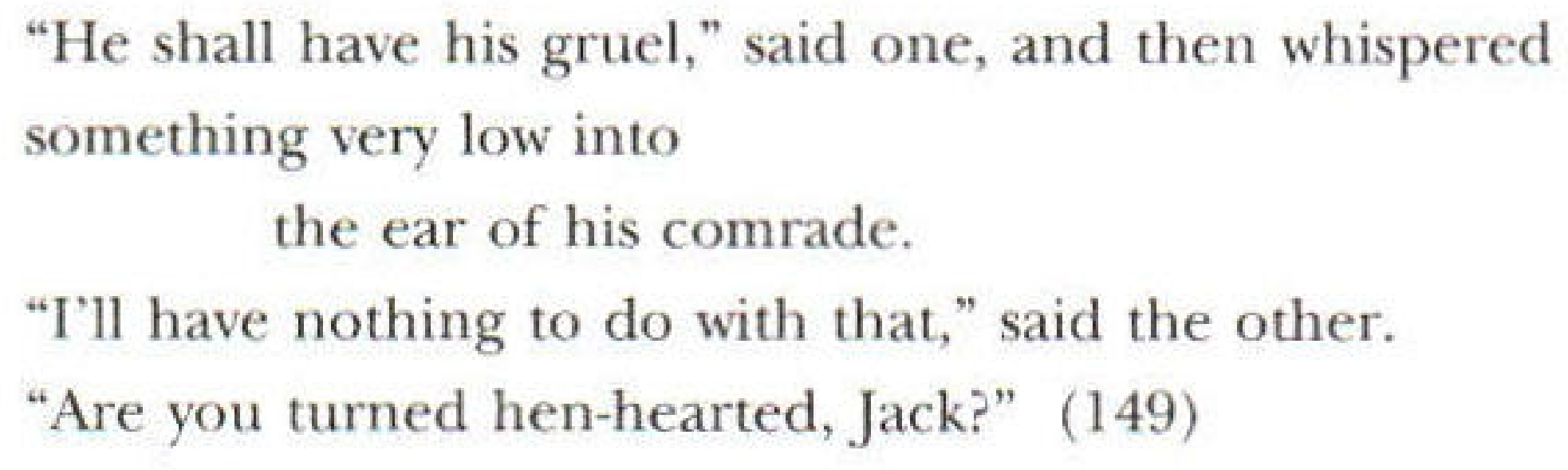

After more of their conversation, Scott breaks off, observing that the men continued with "more of this gibberish" (149), which was not worth recording. The narrative viewpoint here is ambiguous: to whom the talk "gibberish"-Bertram? the narrator? the implied reader? Many listeners would find it gibberish, in any case: the men's cant is, "even to each other, a dark obscure dialect, eked out by significant nods and signs, but never expressing distinctly, or in plain language, the subject on which it turned" (150). Sometimes the context clarifies a word for both Bertram and the reader, such as when Meg refers to "these very fambles" and holds up her hands (149), but generally Scott keeps the dialect "dark" and "obscure" neither paraphrasing not providing footnotes. Years later, Scott decided that if he were to include so much cant, then some of it should be translated: for the $1829 \mathrm{Mag}$ num Opus edition of Guy Mannering he added notes to gloss many terms, much as Bulwer added notes in the 1840 edition of Pelham.

In Scott's “The Surgeon's Daughter," published twelve years after Guy Mannering, Richard Middlemas, tricked into enlisting in the British East India Company, drugged and robbed, wakes to find himself confined in a military hospital. Some of the nearby patients "whispered to each other in canting language, upon schemes which, as far as a passing phrase could be understood by a novice, had relation to violent and criminal exploits" (212). As it happens, these men are not specifically trying to hide anything from Middlemas, but they might try to. The word "novice" is important: the community constituted by this cant has several stages of initiation. This passage evokes Middlemas's viewpoint, and so he is the listener whom Scott depicts not as an utter outsider but as a novice, one who knows little but who is aware of his ignorance and who has been placed, by choice or necessity, on the path to knowledge.

When the eponymous hero of Bulwer's Paul Clifford enters Bridewell Prison after being unjustly arrested as a pickpocket's accomplice, he has an odd encounter: "a tall gentleman marched up to him, and addressed him in a certain language, which might be called the freemasonry of flash; and which Paul, though he did not comprehend verbatim, rightly understood to be an inquiry whether he was a thorough rogue and an entire rascal" (73). Paul is asked, that is, whether he is full flash; indeed, "full flash" may be the phrase the gentleman used. The freemasonry does not exclude Paul, since the tall gentleman expects that Paul might understand what he hears. Indeed, Paul's comprehending the question would show that he does. Paul, who was raised in a "flash ken" (69) and has moved in semi-fashionable flash circles, believes he makes out the man's import, and Bulwer confirms that Paul is correct, even though Paul's reply to the man is so unsatisfactory that he is assaulted. (The assault, the narrator explains shortly, is that "initiatory process, technically termed 'ramping,' and exercised upon all new comers who seem to have a spark of decency in them" [73], and the gentleman turns out to be Paul's old friend, the journalist and man-about-town Augustus Tomlinson.) One of Bulwer's aims in Paul Clifford, he acknowledged in a preface he added to the book in 1840 , was to demonstrate that fashionable slang "is but an easy paraphrase of" vulgar cant (v). Even if one slang does not literally paraphrase another, they function similarly and serve similar ends. When Bulwer refers to "the freemasonry of flash," he makes explicit the analogy between criminal flash and other forms of secret association, and he alerts us to the ways in which the various forms of secrecy and the various reasons for secrecy could serve as figures for each other.

In Guy Mannering, "The Surgeon's Daughter," and Paul Clifford, the newcomer can interpret only part of what is said, and uncertainly at best: Bertram can gather their meaning "in general," yet "much of their conversation" remains 
obscure; Middlemas interprets accurately "as far as a passing phrase could be understood by a novice"; Clifford distinguishes "rightly" the main idea, but he "did not comprehend verbatim." Each of the narrators, in contrast, appears omniscient: he can identify the dialect as "canting language" (Mannering 149, "Surgeon" 212) or as the "certain language" that serves as "the freemasonry of flash"; he knows what all the words mean (even though he may not tell what those words are), and he can evaluate the accuracy of his character's interpretations. $^{6}$ Guy Mannering excludes the reader by not translating the cant, so one knows only what Bertram knows, and then the narrator gives up recording words that will appear to be merely "gibberish." "The Surgeon's Daughter" and Paul Clifford refuse, at least momentarily, to reveal what the specific flash words are, much less what they mean.

Treating the reader as a "flat," an outsider, became a convention: in Oliver Twist (1837-39), for example, Dickens stands between the reader and the speech of the housebreaker Bill Sikes. When Sikes first appears, the narrator points out that he relies on underworld lingo: "in cant terms, with which his whole conversation was plentifully besprinkled, but which would be quite unintelligible if they were recorded here, [Sikes] demanded a glass of liquor" (137). When Sikes asks for a drink, there is no outsider like Bertram, Middlemas, or Clifford present, just Fagin's associates and the uninitiated reader. Dickens, knowing that his readers could not decode the cant, declines to explicate it in the manner of Egan's Life in London, or even to supply the actual language: rather than reproduce Sikes' speech, Dickens summarizes, with an anticlimactic result: Sikes "demanded a glass of liquor." Not all translations of flash are so neutral: in Paul Clifford Bulwer replaces the tall gentleman's words with pejorative terms favored by the dominant culture, so that a man who would call himself "full flash" is instead deemed a "thorough rogue," an "entire rascal."

In the scenes I have discussed, the authors aim for a specific effect: in "The Surgeon's Daughter," Scott records some cant; in Paul Clifford, Bulwer reproduces and footnotes cant words; and at several points in Oliver Twist, Dickens records his characters' slang terms (note the editor's glossary, 246). Yet, in the scenes summarized above, the reader is treated as an uninitiated spectator who is excluded, a "flat," an outsider, who is not invited to become even half-flash. The reader may possess enough prior knowledge and deductive ability to interpret as well as Bertram, Middlemas, or Clifford, but maybe not. In "The Surgeon's Daughter" and Paul Clifford, the reader is denied the opportunity, since the narrator withholds the actual flash.

It appears that the narrator is as flash as the flashmen, the observer like Clifford at most quarter- or half-flash, and the reader is a "flat." But not even that much is certain. Perhaps the narrator wants to keep real flash from his readers, or perhaps he really isn't sure of it himself. The narrator may himself be less flash. Dickens writes that Sikes's terms "would be quite unintelligible if they were recorded here," as if to say, there's no point in telling you what his exact words were, since you wouldn't understand them. After all, as Potter wrote in his dictionary, cant is "unintelligible, and unknown to honest Men," and Dickens assumes his readers are honest. Yet Sikes's cant terms cannot be so difficult that a few footnotes would not clarify them. In fact, it is also possible that the reader might understand these terms better than a middleclass novelist; he or she might be better prepared than Dickens to translate such words if they were uttered by a real criminal-or might be better prepared to tell Dickens how he had misused them! Why would Sikes's cant terms be "unintelligible" to Dickens's 1837 reader-because they had not been included in any of the numerous dictionaries of flash or in earlier Newgate novels like Bulwer's or Ainsworth's? Or would they be unintelligible because they are real criminal slang instead of words (such as "ken" for house) that had been clichés for so long that no real criminal would use them? In fact, most of the slang that Dickens prints in Oliver Twist was old by 1837.

Reticence like Dickens's betrays as much anxiety as self-confidence. In the Bridewell scene in Paul Clifford, the narrator's point may be that Tomlinson speaks to Paul in real criminals' flash, unlike the ersatz or obsolete flash that books like Life in London had made clichés, and that Bulwer had used up to this point in the text. Paul encounters someone more flash than himself, and possibly more flash than Bulwer. When Scott does reveal actual flash conversation in "The Surgeon's Daughter," the flash terms could be found in Grose and other lexicons, and some words, like "hog" for shilling, "ken" for house, and "cull" for man, go back to the sixteenth or seventeenth centuries (Scott 213, 216). ${ }^{7}$ Even if the words would mystify Middlemas in the late eighteenth century, they would be familiar to Scott's reader in 1827 . Yet the antiquity and familiarity of Scott's words make one suspect that they are offered up as substitutes for the codes that real criminals use. However Egan may want readers of Life in London to become "down" to slang, he is ultimately discouraging: Tom's warning ("whisper into your own ear, and make an allowance that there are to be found in company persons as knowing as yourself, if not more knowing!") surely applies not only to Jerry's education but to the reader's, and perhaps the narrator's and author's, as well.

Middlemas and Clifford are disadvantaged when they hear criminal flash, but they should not be too distressed, since flash is nearly a universal characteristic of writing and speaking. Badcock defined slang as "language, words, phrases, invented by doctors and boxers, lawyers, thieves, sportsmen and whores, necessarily or purposely to convey their meaning secretly to each other" (Badcock 158). In Life in London, Egan notes that although actors "have a slang, or cant of their own," they are "like most other professions" in this respect (324). Similarly, "The Surgeon's Daughter" reveals doctors' slang, and the advantage of its opacity. Although Middlemas is excluded from the thieves' conversa- 
tions, his medical training enables him to exclude them from his: his onetime friend and rival Adam Hartley whispers to him in Latin so that the coarser patients will not understand (Chronicles 217). Scott explains that Hartley and Middlemas know Latin because "in that time the medical studies at the celebrated University of Edinburgh were, in a great measure, conducted in Latin" (217). Scott makes a point of attributing their skill in Latin to a specific profession, one noted, then as now, for its distinctive cant. Hartley's conversation with Middlemas is a reminder that criminal lingo mirrors the cants that mark professions.

Just as doctors buttress their authority by means of cant, so do writers, whether novelists or journalists. Badcock takes note of the "Slang of Periodical Literature" (159), citing an example from Blackwood's. Periodical slang is an object of Bulwer's satire in Paul Clifford. Peter Mac Grawler (a caricature of Fraser's Magazine editor William Maginn) offers to tutor Paul in periodical criticism, and Paul knows that he must "either pick pockets or write (not gratuitously)" (51). If criminal flash is "freemasonry" insofar as it both keeps information restricted and marks its users as a community, the rhetoric of reviewing is equally esoteric, as Mac Grawler's choices of metaphors remind Paul: the journalist, deeming himself "a profound adept" in reviewing, agrees to "initiate" Paul (48). Mac Grawler has three methods: plastering (indiscriminate praise), slashing (indiscriminate abuse), or tickling, which "comprises all the infinite varieties that fill the interval between slashing and plastering" (48). Tickling, according to Mac Grawler, is the "great mystery of our science" (48) and a form of slang, albeit an oddly self-reflexive one: "all tickles may be supposed to signify, however disguised, one or other of these meanings: 'This book would be exceedingly good if it were not exceedingly bad'; or, "This book would be exceedingly bad if it were not exceedingly good'” (49). The flash of "tickling" serves Mac Grawler well because it creates the illusion he says something substantial. The disguised meanings are so benignly nonsensical that they can epitomize the modes of secrecy that exist to demarcate a profession rather than hide a dangerous truth-the only secret is the absence of a secret.

Moreover, because one mysterious word can easily fulfill another's duty, different varieties of flash can be enlisted by a reviewer to create the illusion of profundity. Paul distinguishes himself in his Asinaeum articles by introducing flash terms like "bustle" and "buzz gloak," which readers hail as "enigmatical words and recondite phrases" (53). Paul replaces Mac Grawler's flash with the criminal flash he has encountered since childhood. Bulwer not only compares reviewers' clichés to criminal cant, but compares both to the cant of philosophers: in the eyes of readers, Paul's "unintelligible sublimity" resembles that of "a poet from Highgate, or a philosopher from Köningsburg.” Bulwer's allusions to Coleridge and Kant are to the point: thieves, reviewers, and philosophers all have their cants, which protect, even legitimate their professional expertises.
If journalism uses a cant, so does fiction. Being "flash to" hidden meanings is a central theme of Paul Clifford: it dramatize slangs of criminals, journalists, and sportsmen and it contains its own latent meanings. Besides caricaturing literary men like Maginn, the novel also satirizes the Tory government that was in power in 1830. Fielding attacked the "great man" Robert Walpole in the figure of the notorious fence and thief-taker Jonathan Wild; Bulwer in his band of criminals provides portraits of the Duke of Wellington, Lord Eldon, and George IV. Yet his political satire is itself a kind of flash. The knowledge and awareness that enable the reader to perceive that Fighting Attie is the British Prime Minister Wellington or that Bagshot is Lord Eldon are analogous to the knowledge that a "spellken" is a house where thieves congregate. Ideally, satire like Bulwer's is a cant to which everyone is flash-except the Attorney General.

So, Romantic era literature is a kind of flash. The disguised communication Badcock describes, and the interpretive questions involved in criminal flash, are central to canonical Romanticism. Major texts from the period address their readers as though at least some of them are "knowing" members of a secret fraternity, and Byron's Don Juan and Thomas De Quincey's Confessions of an English Opium Eater, I propose, encourage readers to practice self-admonition like that recommended by Egan's Corinthian Tom: "make an allowance that there are to be found in company persons as knowing as yourself, if not more knowing!" Encryption, and fascination with encryption, is a counterweight to political and aesthetic insistence on sincerity. When Romantic fiction seems to invite us to read as criminals, it can be reminding us that we may always be "flats."

\section{NOTES}

${ }^{1}$ On seventeenth- and eighteenth-century cant dictionaries, Gotti, The Language of Thieves and Vagabonds (1999).

${ }^{2}$ Badcock asserts that an outsider, or "flat," "may avoid much evil by studying these pages" (80). Pierce Egan aimed in his 1823 revision of Grose's dictionary to "put the UNWARY on their guard; to arouse the sleepy, and to keep them AWAKE; to render those persons who are a little UP, more FLY: and to cause every one to be down to those tricks, manœœuvres, and impositions practised in life, which daily cross the paths of both young and old" (xxviii). The editor of Lexicon Balatronicum admits he catalogues these words so that his reader may adopt them, but he persists in claiming moral purposes (vii).

${ }^{3}$ Dyer (567) on how flash could have this broader sense.

${ }^{4}$ Thomas Moore commented in Tom Crib's Memorial to Congress (1819) that "To be down to any thing is pretty much the same as being up to it, and 'down as a hammer' is, of course, the intensivum of the phrase" (45n). For more on "flash" as knowingness, Dyer, 566567. 
${ }^{5}$ Though Meg, a gypsy, "uses the canting language of her tribe" (25), the words Scott has her use are not Romany but underworld cant, as Graham Tulloch (32) and Peter Garside (Mannering 523n) point out. The present essay disregards the broad issue of how cant fits into the other dialects in Scott's fiction. Certainly Scott produces some odd effects. In The Heart of Mid-lothian (1817), Daddie Ratton gives Jeanie Deans samples of "rogue's Latin" that she finds "totally unintelligible" (246-47), but I suspect English readers did not find Ratton's cant any more troublesome than his Scots.

6In the passages in Guy Mannering and "The Surgeon's Daughter" where the narrator refers to the dialect as "canting language," he is describing events from the viewpoint of Bertram or Middlemas, implying that the two novices identify the language, even though they cannot translate it.

${ }^{7}$ Scott employs cant in the period novels The Fortunes of Nigel, Kenilworth, and Peveril of the Peak, which take place from the fifteenth to the seventeenth centuries (Tulloch 75-78).

\section{WORKS CITED}

George Andrewes, Dictionary of the Slang and Cant Languages: Ancient and Modern (1809); Jon Bee [John Badcock], Slang: A Dictionary of the Turf, the Ring, the Chase, the Pit, of Bon-Ton, and the Varieties of Life, Forming the Completest and Most Authentic Lexicon Balatronicum Hitherto Offered to the Notice of the Sporting World (1823); Edward Bulwer, Paul Clifford, Tomlinsoniana, and Eugene Aram (n.d.); Edward George Bulwer-Lytton, Pelham or The Adventures of a Gentleman, ed. Jerome J. McGann (1972); Lord By- ron, Don Juan, in The Complete Poetical Works, ed. Jerome J. McGann (1980-93) 5: 3-662; Charles Dickens, Oliver Twist, ed. Peter Fairclough (1966); Gary Dyer, "Thieves, Boxers, Sodomites, Poets: Being Flash to Byron's Don Juan," PMLA 116:3 (2001), pp. 562-78; Pierce Egan, Life in London; or, The Day and Night Scenes of Jerry Hawthorn, Esq. and His Elegant Friend Corinthian Tom, Accompanied by Bob Logic, the Oxonian, in Their Rambles and Sprees Through the Metropolis (1821); Pierce Egan, Grose's Classical Dictionary of the Vulgar Tongue, Revised and Corrected, with the Addition of numerous Slang Phrases, Collected from Tried Authorities (1823); Maurizio Gotti, The Language of Thieves and Vagabonds: 17th and 18th Century Canting Lexicography in England (1999); [Francis Grose,] Lexicon Balatronicum. A Dictionary of Buckish Slang, University Wit, and Pickpocket Eloquence. Compiled Originally by Captain Grose. And Now Considerably Altered and Enlarged, with the Modern Changes and Improvements, by a Member of the Whip Club (1811); Samuel Johnson, A Dictionary of the English Language (1755); One of the Fancy [Thomas Moore], Tom Crib's Memorial to Congress (1819); Humphry Tristram Potter, A New Dictionary of All the Cant and Flash Languages, Both Ancient and Modern ([1800?]); Walter Scott, Guy Mannering (1999); Walter Scott, "The Surgeon's Daughter," in Chronicles of the Canongate, ed. Claire Lamont (2001), pp. 158-286; Walter Scott, The Heart of Mid-lothian (1982); Graham Tulloch, The Language of Walter Scott: A Study of His Scottish and Period Language (1980); James Hardy Vaux, Memoirs of James Hardy Vaux (1819). 